\title{
The isolation and composition of the major glycoprotein from human gastric aspirates
}

\author{
J. SCHRAGER AND M. D. G. OATES \\ From the Group Laboratory, Royal Albert Edward Infirmary, Wigan, Lancashire
}

SUMMARY The isolation of the principal glycoprotein from human gastric aspirates and the determination of its carbohydrate and amino acid composition is described.

Ninety-nine individual gastric aspirates were investigated. Eighty-two were eluted on Bio-gel P150 and the carbohydrate and amino acid composition of each non-retarded fraction was determined. Fifteen of these non-retarded fractions were chromatographed again on Ecteola cellulose. Seventeen aspirates were precipitated with cetylpyridinium chloride. The carbohydrate, amino acid, and sulphate contents of the subfractions eluted on Ecteola cellulose and cetylpyridinium chloride precipitates were determined.

The results suggest that the non-retarded fractions are composed of glycoproteins with a constant basic composition but polydisperse with respect to the sulphate contents and the terminal sugar residues which are associated with blood group specificity. It was found possible to correlate and identify in chemical terms the blood group specificity of all the glycoproteins investigated. No significant differences were detected between the carbohydrate and amino acid composition of each of the non-retarded fractions, the subfractions eluted on Ecteola cellulose, and the cetylpyridinium chloride precipitates. The sulphate content of the isolated glycoproteins was found to vary between zero and a sulphate: glucosamine ratio of 2:3. The subfractions of Ecteola cellulose showed that $20-50 \%$ of the glycoproteins were sulphated. The data also suggest that the isolated glycoprotein is the principal carbohydrate-containing fraction of the gastric secretion as it contained $68-96 \%$ of the total carbohydrate content of the gastric aspirates investigated.

Aspirated gastric secretions contain gelatinous lumps which can be packed down by centrifugation. The deposit forms the so-called 'visible' mucus as distinct from the 'soluble' mucus contained in the supernatant (Babkin, 1950).

A recent paper from this laboratory described the isolation of a glycoprotein from the supernatant of gastric aspirates (Schrager and Oates, 1970). That paper also reported the carbohydrate and amino acid composition of the isolated glycoprotein and its partial characterization. The investigation described in the present paper is an extension of previous studies. Its purpose was the isolation of the glycoprotein from the whole gastric aspirate containing both the 'soluble' and 'visible' mucus, using gel chromatography; the isolation of the glycoprotein by a method unrelated to gel chromatography; and the study of the degree of sulphation and the Received for publication 18 February 1971. quantitative relationships between the sulphated and non-sulphated glycoprotein.

Pilot experiments had shown that cetylpyridinium chloride precipitates carbohydrate-containing fractions of gastric aspirates, confirming the findings of other workers (Martin, Mathian, Berard, and Lambert, 1969), and so precipitation of gastric aspirates with cetylpyridinium chloride was selected as an alternativeseparation procedure. Chromatography again on Ecteola cellulose was used to study the degree of sulphation of the isolated glycoprotein. The results are reported and discussed.

\section{Materials and Methods}

\section{GASTRIC SECRETION}

The method employed has been described (Schrager, 1964; Schrager and Oates, 1970). The pooled aspirates of each subject investigated were incubated 
with pepsin for $48 \mathrm{hr}$ at $37^{\circ}, p \mathrm{H} 1.5$ (pepsin:substrate $-1: 20$ ) and centrifuged for $30 \mathrm{~min}$ at room temperature swing-out head at $2,500 \mathrm{~g}$. The deposit, consisting of cell debris as shown by stained smears, was discarded. Adequate quantities $(5 \mathrm{ml})$ of the supernatant were taken to determine the carbohydrate components, sulphate and sialic acid.

Ninety-nine individual gastric aspirates were investigated as follows.

Each of 82 aspirates was eluted on Bio-gel P150. Preliminary examinations had shown that the peak eluted at the void volume, the non-retarded fraction, contained $68-96 \%$ of the total carbohydrate put on the column. It was, therefore, selected as the subject matter of this study. The carbohydrate, amino acid, sulphate, and sialic acid contents of each nonretarded fraction were determined.

Fifteen non-retarded fractions were chromatographed again on Ecteola cellulose.

Seventeen individual aspirates were precipitated with cetylpyridinium chloride.

The carbohydrate, amino acid, sulphate, and sialic acid contents of the subfractions eluted on Ecteola cellulose and the cetylpyridinium chloride precipitates were determined.

The gel filtration procedure and the methods for the carbohydrate, amino acid, sulphate, and sialic acid analyses have been described (Schrager and Oates, 1970).

\section{AMINO ACID ANALYSIS}

The non-retarded fraction was incubated with pepsin for $48 \mathrm{hr}$ at $37^{\circ}, \mathrm{pH} 1.5$ and chromatographed twice again to reduce the impurities to a minimum. Portions were hydrolysed in $4 \mathrm{~N} \mathrm{HCl}$ at $100^{\circ}$ for $18 \mathrm{hr}$ at a concentration of approximately $3 \mathrm{mg} / \mathrm{ml}$. These were found to be optimum conditions for the release of the amino acids. After hydrolysis the solutions were evaporated to dryness in a vacuum desiccator over $\mathrm{NaOH}$. The dried residue was dissolved in $0 \cdot 1 \mathrm{~N} \mathrm{HCl}$ and amino acid analysis was carried out on the Technicon AutoAnalyzer (Technicon Instruments Ltd, Co, Chertsey, Surrey).

\section{eCteola CELlulose ColumN}

Ecteola cellulose (Whatman ET11) was cleaned by placing the slurry of the material in a Buchner funnel and washing with sodium hydroxide $(0.5 \mathrm{~N})$ followed by water and $\mathrm{HCl}(0.5 \mathrm{~N})$; the process was repeated and the material finally washed with distilled water. The Ecteola cellulose was then packed into a glass column $(30 \mathrm{~cm} \times 0.6 \mathrm{~cm})$ using air pressure (20 psi) to obtain an even stable packing at the top of the column and a reasonable flow rate. The column was finally equilibrated with the starting buffer $(0 \cdot 05 \mathrm{M} \mathrm{NaCl})$.

\section{STEPWISE ELUTION}

After equilibration the sample $(5-10 \mathrm{ml})$ was placed on the column and when fully absorbed the column was eluted with the required buffer (approximately $150 \mathrm{ml}$ ) before changing to the next one. Fractions $(5 \mathrm{ml})$ were collected and monitored by ultraviolet absorption $(280 \mathrm{~nm})$ measurements and also by orcinol/sulphuric acid determinations.

CETYLPYRIDINIUM CHLORIDE PRECIPITATION A modified method of Martin et al (1969) was used. The supernatant of the homogenized gastric secretion was incubated with pepsin for $48 \mathrm{hr}$ at $p \mathrm{H} 1.5$ (pepsin: substrate-1:20) and dialysed against distilled water. Gastric secretion was then made up to $1 \%$ cetylpyridinium, allowed to stand at room temperature for at least six $\mathrm{hr}$, and then centrifuged. The cetylpyridinium chloride complex of the sulphated glycoprotein was dissolved in $1 \%$ sodium acetate. The sulphated glycoproteins, free of cetylpyridinium chloride, were precipitated with 4 volumes of ethanol $(95 \%)$ and 0.2 volumes of saturated sodium acetate and re-dissolved in $0.1 \mathrm{M}$ $\mathrm{NaCl}$. The carbohydrate, amino acid composition, and the sulphate contents were determined.

\section{AGGLUTINATION INHIBITION}

The method used was that described by Boorman and Dodd (1966).

\section{Results}

Gel chromatography resolved the gastric aspirates into three fractions (Fig. 1). A non-retarded fraction showing a symmetrical peak of totally excluded material and containing $64-92 \%$ of glucosamine and $72-100 \%$ of the galactosamine put on the column, a second fraction consisting mainly of pepsin, and a third fraction of polypeptides. The carbohydrate material not eluted with the first peak was unevenly distributed between the second and third peaks. The non-retarded fraction yielded on acid hydrolysis galactose, fucose, galactosamine, and glucosamine; it also contained sulphate.

QUANTITATIVE RELATIONSHIPS OF THE CONSTITUENT MONOSACCHARIDES

The quantitative relationships of the carbohydrate components of the non-retarded fraction are summarized in Table I. The analyses demonstrate that they are similar to the carbohydrate components of the non-retarded fraction obtained from the supernatant (Schrager and Oates, 1970). The analytical data showed a common basic composition with the quantitative relationship of galactose: glucosamine: galactosamine of $4: 3: 1$. The results gave 
integral residue ratios within the limits of the experimental error $( \pm 5 \%)$.

Superimposed on the basic common structure were additional sugar residues which divided the glycoproteins into groups, each group with a characteristic sugar residue associated with a distinctive blood group specificity. No differences were found between the glycoproteins of whole gastric aspirates and the glycoproteins isolated from the supernatant alone (Schrager and Oates, 1970).

The glycoproteins of groups 1 and 2 showed the same quantitative relationships of galactose:glucosamine:galactosamine, namely, $4: 3: 1$, but they differed in their fucose content, those of group 1 having a lower fucose content. The glycoproteins of group 1 showed neither A, H, nor B blood group specificity; the increase of fucose in the glycoproteins of group 2 was associated with blood group specificity $\mathrm{H}$. The glycoproteins of groups 3 and 4 had an additional galactosamine and galactose residue respectively, the former being associated with blood group specificity $\mathbf{A}$ and the latter with blood group

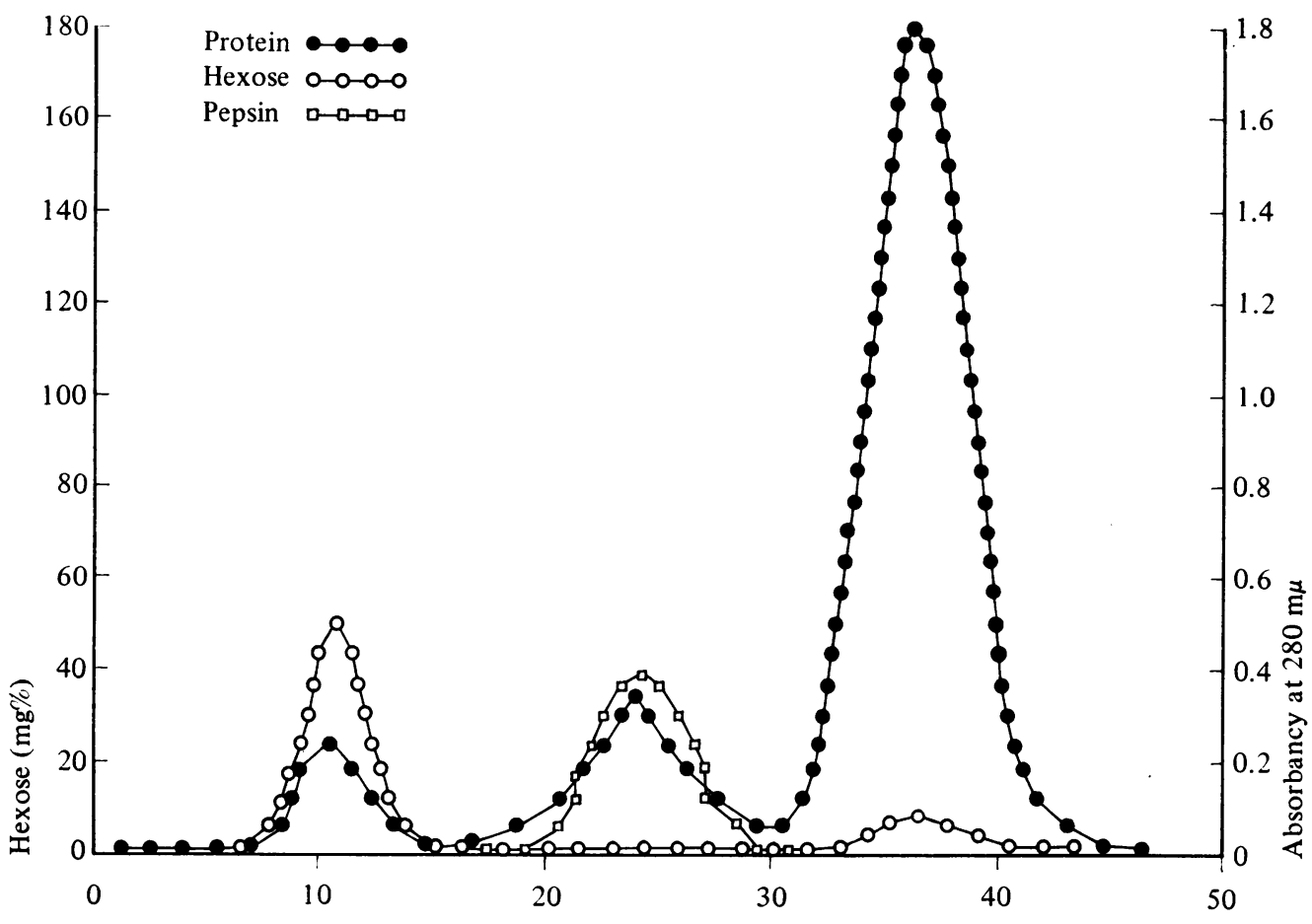

Fraction number

Fig. 1 Elution pattern from Bio-gel 150. Elution carried out with 0.05M sodium chloride. Fractions of $15 \mathrm{ml}$ were collected. Elution rate 15 to $20 \mathrm{ml}$ per hour.

\begin{tabular}{|c|c|c|c|c|c|}
\hline Carbohydrate Component & $\begin{array}{l}\text { Group 1: Non- } \\
\text { secretor }\end{array}$ & $\begin{array}{l}\text { Group 2: Specificity } \\
H\end{array}$ & $\begin{array}{l}\text { Group 3: Specificity } \\
A \& H\end{array}$ & $\begin{array}{l}\text { Group 4: Specificity } \\
B \& H\end{array}$ & $\begin{array}{l}\text { Group s: Specificity } \\
A, B, H\end{array}$ \\
\hline $\begin{array}{l}\text { Galactose } \\
\text { Glucosamine } \\
\text { Galactosamine } \\
\text { Fucose } \\
\text { Sulphate }\end{array}$ & $\begin{array}{l}3.99 \pm 0.01(9)^{2} \\
3.00 \\
0.97 \pm 0.05(9) \\
1.60 \pm 0.17(9) \\
2.53 \pm 1.90(3)\end{array}$ & $\begin{array}{l}3.92 \pm 0.09(26) \\
3.00 \\
1.05 \pm 0.05(26) \\
2.60 \pm 0.22(26) \\
1.18 \pm 0.34(19)\end{array}$ & $\begin{array}{l}3.92 \pm 0.11(45) \\
3.00 \\
1.56 \pm 0.22(45) \\
2.61 \pm 0.16(45) \\
1.29 \pm 0.84(33)\end{array}$ & $\begin{array}{l}5.00(1) \\
3.00 \\
1.00(1) \\
3.00(1) \\
0.14(1)\end{array}$ & $\begin{array}{l}4.90(1) \\
3.00 \\
1.20(1) \\
3.00(1) \\
0.48(1)\end{array}$ \\
\hline
\end{tabular}

Table I Carbohydrate components of the eluted non-retarded fractions of 82 individual gastric aspirations 1

${ }^{1}$ Results expressed as mean \pm SD Ratio of carbohydrate components to glucosamine $(=3.0)$

Number of aspirates 


\begin{tabular}{|c|c|c|c|c|}
\hline Galactose & Fucose & Glucosamine & Galactosamine & $\begin{array}{l}\text { Haemoagglutination Titre } \\
1 \text { ml of Glycoprotein } \\
\text { Diluted with: }\end{array}$ \\
\hline $\begin{array}{l}0.46(4.00) \\
0.40(4.00) \\
0.49(4.13) \\
0.48(4.10) \\
0.54(4.10) \\
0.58(3.86)\end{array}$ & $\begin{array}{l}0.27(2.37) \\
0.25(2.48) \\
0.28(2.41) \\
0.28(2.54) \\
0.33(2.50) \\
0.30(2.00)\end{array}$ & $\begin{array}{l}0.34(3.00) \\
0.30(3.00) \\
0.35(3.00) \\
0.35(3.00) \\
0.41(3.00) \\
0.45(3.00)\end{array}$ & $\begin{array}{l}0.13(1.20) \\
0.13(1.30) \\
0.20(1.60) \\
0.19(1.60) \\
0.26(2.00) \\
0.30(2.00)\end{array}$ & $\begin{array}{l}1 \mathrm{ml} \text { saline } \\
1 \mathrm{ml} \text { saline } \\
3 \mathrm{ml} \text { saline } \\
4 \mathrm{ml} \text { saline } \\
6 \mathrm{ml} \text { saline } \\
8 \mathrm{ml} \text { saline }\end{array}$ \\
\hline
\end{tabular}

Table II Carbohydrate composition of six glycoproteins of blood group A activity

specificity B. These findings are in agreement with those of Morgan and Lloyd and their collaborators in their studies of the glycoproteins of pseudomucinous cysts (Morgan and Watkins, 1969; Lloyd, Kabat, and Licerio, 1968).

Table I clearly shows that it is possible to correlate the blood group specificity of any individual gastric secretion with the quantitative analysis of the monosaccharides forming the sugar moiety of the glycoprotein. It will also be noticed that while the carbohydrate components of the basic common structure showed stoichiometrical relationships, the additional sugar residues associated with blood group specificity revealed a limited degree of variations. The galactosamine:glucosamine ratio of group 3 (blood group specificity A) varied between $1 \cdot 2: 3$ and $2: 3$. Similar variations were found in the galactose: glucosamine ratio of group 4 (blood group specificity B). Variations in the determining sugar residues were also reported in the glycoproteins of pseudomucinous cysts (Morgan and Watkins, 1969; Lloyd et al, 1968).

HAEMOAGGLUTINATION INHIBITION TITRE OF SIX INDIVIDUAL NON-RETARDED FRACTIONS WITH BLOOD GROUP SPECIFICITY A

The haemoagglutination inhibition titre of serial dilutions of six individual non-retarded fractions were determined. The results are summarized in Table II. The level of the haemoagglutination inhibition titre of each non-retarded fraction investigated appeared to be related to the galactosamine:glucosamine ratio of the fraction. A high haemoagglutination inhibition titre corresponded to a high galactosamine:glucosamine ratio. No attempt was made to correlate the fucose glucosamine ratio with the haemoagglutination inhibition titre of glycoproteins showing blood group $\mathrm{H}$, as fucose, the sugar residue associated with blood group specificity $\mathbf{H}$, already showed some variation in the basic composition (group 1) thus making any quantitative correlation difficult (Table I).

This is the first time, as far as we are aware, that a definite relationship between quantitative analyses of the sugars has been correlated with the haemo- agglutination inhibition titre of the glycoproteins investigated.

\section{RECOVERY}

The recoveries of the carbohydrate content put on the column are given in Table III. The data showed that the non-retarded fractions contained $64-92 \%$ of the glucosamine and $72-100 \%$ of the galactosamine content eluted from the column. The recovery of galactosamine in the non-retarded fraction was higher than that of glucosamine and is explained by the fact that a portion of the glucosamine in the gastric aspirates is contributed by the plasma glycoproteins present in gastric secretion (Schultze and Heremans, 1966).

\begin{tabular}{lcccc}
\hline Put on Column & & \multicolumn{2}{l}{ Non-retarded Fraction } \\
\cline { 1 - 2 } Glucosamine & Galactosamine & & Glucosamine & Galactosamine \\
\hline 27.60 & 8.70 & $20.02(78 \%)$ & $7.87(92 \%)$ \\
24.00 & 7.84 & $17.27(71 \%)$ & $6.18(78 \%)$ \\
31.50 & 12.00 & $27.04(85 \%)$ & $11.44(95 \%)$ \\
94.00 & 55.20 & $70.40(74 \%)$ & $42.82(77 \%)$ \\
53.00 & 27.72 & $34.28(64 \%)$ & $22.48(81 \%)$ \\
24.12 & 14.88 & $21.07(87 \%)$ & $11.52(77 \%)$ \\
13.44 & 6.00 & $11.32(85 \%)$ & $5.09(84 \%)$ \\
34.24 & 11.68 & $31.81(92 \%)$ & $11.88(100 \%)$ \\
38.40 & 12.24 & $26.07(67 \%)$ & $11.55(94 \%)$ \\
23.50 & 9.80 & $21.28(90 \%)$ & $9.60(97 \%)$ \\
18.63 & 6.04 & $14.00(75 \%)$ & $4.75(78 \%)$ \\
14.49 & 4.09 & $9.96(68 \%)$ & $3.16(76 \%)$ \\
19.55 & 7.01 & $12.60(64 \%)$ & $5.18(72 \%)$ \\
15.30 & 6.42 & $10.50(68 \%)$ & $5.88(91 \%)$ \\
15.15 & 9.00 & $12.25(80 \%)$ & $7.50(83 \%)$ \\
\hline
\end{tabular}

Table III Recovery of carbohydrate components of each of 15 gastric aspirations of the non-retarded fractions ${ }^{1}$

${ }^{1}$ The quantities are expressed in micromoles

The isolation procedure adopted in this work was based on the observation that the gastric glycoprotein is not susceptible to proteolytic attack by papain or pepsin whereas the plasma glycoproteins are digested by these proteolytic enzymes (Porter, 1967). Therefore, on eluting gastric aspirates digested by pepsin, the fragmented plasma glycoproteins are retarded during chromatography on Bio-gel P150 and are not included in the non-retarded peak containing the gastric glycoprotein. As the hexosamine content of the plasma glycoprotein consists 
mainly of glucosamine (Schrager and Oates, 1970), a large proportion of the glycoprotein will appear in the various retarded fractions containing the fragmented plasma glycoproteins hence the lower recovery of the glucosamine in the non-retarded fraction.

\section{AMINO ACID ANALYSIS}

Amino acid analyses of 14 non-retarded fractions were determined (Table IV). They showed the same characteristic composition as was found in the nonretarded fractions of the eluted supernatant (Schrager and Oates, 1970). Threonine and serine constitute $45-50 \%$ of the amino acid content. The ratio of threonine to serine was found to be approximately $2: 1$. Threonine, serine, proline, alanine, and glycine made up $75-80 \%$ of the total amino acid content.

Quantitative relationships were also found between the hydroxy amino acids and galactosamine (Table
V). The amount of threonine plus serine approximated to that of galactosamine in all cases except in aspirations of group 3. The non-retarded fraction of group 3, blood group specificity A, contained more galactosamine. The ratio of glucosamine to galactosamine in glycoproteins of group 3 varied between $3: 1 \cdot 2$ to $3: 1 \cdot 8$ instead of $3: 1$.

\section{ECTEOLA CELlulose}

Stepwise elution of the non-retarded fraction on Ecteola cellulose resolved the gastric glycoprotein into two or three well separated peaks depending on the number of buffer steps used (Fig. 2). The carbohydrate and amino acid composition of the nonretarded fractions and the subfractions obtained by chromatography a second time on Ecteola cellulose were determined. The results are summarized in Tables VI, VII, and VIII.

The fractions showed virtually the same carbo-

\begin{tabular}{|c|c|c|c|c|c|c|c|c|c|c|c|c|c|c|c|}
\hline \multirow[t]{2}{*}{ Amino Acid } & \multicolumn{15}{|c|}{ Non-retarded Fraction } \\
\hline & 1 & 2 & 3 & 4 & 5 & 6 & 7 & 8 & 9 & 10 & 11 & 12 & 13 & 14 & 15 \\
\hline Aspartic acid & 1.90 & $2 \cdot 00$ & 0.80 & 0.80 & 0.70 & 0.90 & 1.60 & 1.90 & $1 \cdot 20$ & $1 \cdot 10$ & 1.00 & 1.90 & $1 \cdot 30$ & $1 \cdot 60$ & 0.78 \\
\hline Threonine & 10.00 & $10 \cdot 00$ & $10 \cdot 00$ & $10 \cdot 00$ & $10 \cdot 00$ & $10 \cdot 00$ & $10 \cdot 00$ & $10 \cdot 00$ & $10 \cdot 00$ & $10 \cdot 00$ & $10 \cdot 00$ & $10 \cdot 00$ & $10 \cdot 00$ & 10.00 & 10.00 \\
\hline Serine & $5 \cdot 20$ & $5 \cdot 80$ & $5 \cdot 10$ & $5 \cdot 30$ & $5 \cdot 80$ & $5 \cdot 10$ & 5.50 & $5 \cdot 40$ & 6.00 & $5 \cdot 70$ & $5 \cdot 10$ & $5 \cdot 70$ & $5 \cdot 30$ & $5 \cdot 70$ & $5 \cdot 25$ \\
\hline Glutamic acid & 3.00 & $1 \cdot 70$ & 1.90 & $1 \cdot 70$ & 0.80 & 1.80 & $2 \cdot 70$ & $3 \cdot 30$ & $3 \cdot 30$ & $1 \cdot 70$ & 1.50 & $3 \cdot 30$ & 1.80 & $3 \cdot 20$ & 1.75 \\
\hline Proline & $7 \cdot 50$ & - & - & - & $6 \cdot 20$ & $6 \cdot 30$ & $6 \cdot 40$ & $6 \cdot 20$ & 11.00 & $7 \cdot 20$ & - & $8 \cdot 30$ & - & - & - \\
\hline Glycine & 3.70 & $2 \cdot 60$ & $2 \cdot 30$ & $2 \cdot 50$ & $1 \cdot 70$ & $2 \cdot 70$ & $3 \cdot 30$ & 3.40 & $5 \cdot 30$ & 3.00 & 3.00 & $3 \cdot 70$ & $2 \cdot 20$ & 2.90 & 2.63 \\
\hline Alanine & $4 \cdot 40$ & $3 \cdot 70$ & $4 \cdot 10$ & $4 \cdot 30$ & $3 \cdot 10$ & $4 \cdot 50$ & $5 \cdot 40$ & $5 \cdot 40$ & $6 \cdot 40$ & $4 \cdot 50$ & $4 \cdot 30$ & $4 \cdot 10$ & 3.50 & $4 \cdot 50$ & $4 \cdot 18$ \\
\hline Valine & 1.90 & $1 \cdot 50$ & $1 \cdot 20$ & 0.60 & $1 \cdot 10$ & 1.40 & 1.40 & 1.80 & $2 \cdot 40$ & $1 \cdot 10$ & 1.00 & $1 \cdot 30$ & - & $1 \cdot 10$ & $1 \cdot 17$ \\
\hline Isoleucine & - & 0.80 & 0.60 & 0.30 & 0.50 & 0.70 & - & 0.80 & $1 \cdot 10$ & 0.50 & 0.60 & $0 \cdot 70$ & 0.50 & 0.70 & 0.68 \\
\hline Leucine & $1 \cdot 70$ & $2 \cdot 30$ & 1.60 & $1 \cdot 60$ & $1 \cdot 40$ & $1 \cdot 70$ & $1 \cdot 70$ & $2 \cdot 40$ & $2 \cdot 60$ & 1.90 & $1 \cdot 40$ & $2 \cdot 00$ & 1.80 & $1 \cdot 60$ & 1.75 \\
\hline Tyrosine & - & $0 \cdot 60$ & - & - & 0.50 & 0.80 & 一 & - & - & - & - & 0.50 & 0.20 & 0.30 & 0.58 \\
\hline$\beta$ phenylalanine & - & 0.70 & - & - & - & $0 \cdot 70$ & - & 0.50 & 1.00 & $1 \cdot 20$ & - & 0.80 & 0.60 & 1.00 & 0.30 \\
\hline Lysine & 0.90 & 1.00 & - & 0.50 & - & 0.80 & - & $1 \cdot 20$ & $1 \cdot 10$ & 0.80 & 0.80 & $1 \cdot 30$ & 0.80 & 0.70 & 0.68 \\
\hline Histidine & $1 \cdot 10$ & 0.70 & - & 0.60 & - & 0.60 & - & 1.00 & 0.90 & 0.90 & 0.70 & 1.00 & 0.60 & 0.90 & 0.68 \\
\hline Arginine & - & - & - & - & - & - & - & - & - & - & - & $1 \cdot 20$ & - & - & 0.70 \\
\hline
\end{tabular}

Table IV Amino acid composition of 15 representative non-retarded fractions of eluted gastric aspirations ${ }^{1}$

${ }^{1}$ Values are in molar proportions (threonine $=10 \cdot 0$ )

\begin{tabular}{|c|c|c|c|c|c|c|c|}
\hline \multirow[t]{2}{*}{ Total Amino Acids } & \multirow[t]{2}{*}{ Total Sugars } & \multirow{2}{*}{$\begin{array}{l}\text { Percentage of } \\
\text { Sugars in } \\
\text { Glycoprotein }\end{array}$} & \multicolumn{2}{|l|}{ Amino Sugars } & \multirow[t]{2}{*}{ Threonine } & \multirow[t]{2}{*}{ Serine } & \multirow{2}{*}{$\begin{array}{l}\text { Blood Group } \\
\text { Specificity }\end{array}$} \\
\hline & & & Glucosamine & Galactosamine & & & \\
\hline $\begin{array}{l}0.38 \\
0.36 \\
0.27 \\
0.42 \\
0.26 \\
0.70 \\
0.26 \\
0.48 \\
2 \cdot 34 \\
1 \cdot 77 \\
0.89 \\
1 \cdot 44 \\
0.79 \\
2 \cdot 26\end{array}$ & $\begin{array}{r}1 \cdot 83 \\
1.48 \\
1 \cdot 29 \\
2.72 \\
3 \cdot 35 \\
3 \cdot 54 \\
1 \cdot 45 \\
1.91 \\
11 \cdot 48 \\
7 \cdot 12 \\
4 \cdot 16 \\
5.99 \\
3.95 \\
9 \cdot 19\end{array}$ & $\begin{array}{l}82 \\
80 \\
82 \\
86 \\
92 \\
83 \\
81 \\
79 \\
83 \\
82 \\
83 \\
80 \\
83 \\
80\end{array}$ & $\begin{array}{l}0.49 \\
0.43 \\
0.35 \\
0.74 \\
0.88 \\
0.96 \\
0.33 \\
0.58 \\
3.20 \\
2.00 \\
1.26 \\
1.94 \\
0.93 \\
2.61\end{array}$ & $\begin{array}{l}0.30 \\
0.22 \\
0.19 \\
0.34 \\
0.56 \\
0.50 \\
0.11 \\
0.18 \\
1.05 \\
0.66 \\
0.44 \\
0.65 \\
0.31 \\
0.85\end{array}$ & $\begin{array}{l}0.13 \\
0.11 \\
0.08 \\
0.15 \\
0.32 \\
0.25 \\
0.06 \\
0.14 \\
0.67 \\
0.46 \\
0.31 \\
0.45 \\
0.21 \\
0.64\end{array}$ & $\begin{array}{l}0.07 \\
0.06 \\
0.05 \\
0.08 \\
0.17 \\
0.13 \\
0.03 \\
0.07 \\
0.33 \\
0.26 \\
0.18 \\
0.25 \\
0.11 \\
0.35\end{array}$ & 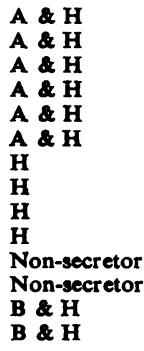 \\
\hline
\end{tabular}

Table V Total amino acid, carbohydrate, threonine, and serine content of the eluted non-retarded fractions of 14 gastric aspirations 1

${ }^{1}$ The percentage of the protein content varies between 12 and $20 \%$. Galactosamine equals approximately threonine + serine except in glycoprotein with blood group specificity A \& H. The quantities are in mmol/litre. 


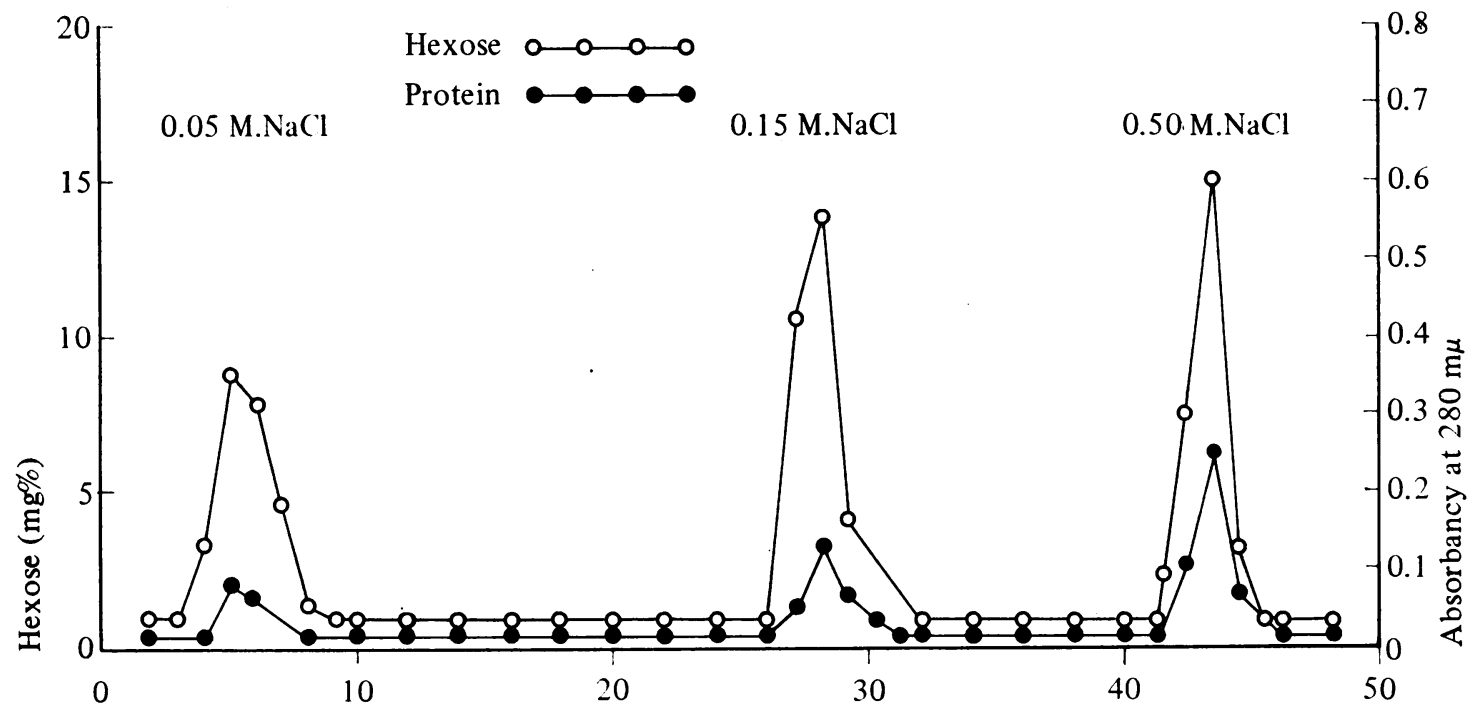

Fraction numbers

Fig. 2 Fractionation of a gastric glycoprotein on a column $(30 \mathrm{~cm} \times 0.6 \mathrm{~cm})$ of Ecteola cellulose. The chromatogram was developed at room temperature by stepwise elution with sodium chloride at the molarities indicated in the figure. The rate of elution was $5 \mathrm{ml} / \mathrm{hr}$ and $5 \mathrm{ml}$ fractions were collected. Each eluted peak was pooled and the sulphate content determined.

hydrate and amino acid composition within the limits of the experimental error of the methods used and did not differ from the composition of the glycoprotein before chromatography again (Table VI). The carbohydrate components showed a similar common basic structure and similar quantitative relationships. No significant differences were noticed between the amino acid composition of the non-retarded fractions and the subfractions from Ecteola cellulose (Table VII). Similar quantitative relationships between the hydroxy amino acids and galactosamine were also found (Table VIII). The only obvious structural variability was found in the sulphate content of the subfractions obtained. The first peak eluted with $0.05 \mathrm{M} \mathrm{NaCl}$ contained very little or no sulphate. With increasing molarity of the eluting salt, the molar ratio of sulphate to glucosamine increased and varied between $1: 3$ and $1: 2$. Thirty-two to $70 \%$ of the glycoproteins were sulphated and eluted in the second and third peak.

CETYLPYRIDINIUM CHLORIDE PRECIPITATION Gastric secretions of 17 individual subjects were precipitated with cetylpyridinium chloride.The carbohydrate, amino acid composition, and the sulphate content of the precipitates were determined. The results are summarized in Tables IX and X. The carbohydrate and amino acid composition of the precipitates was similar to those of the non-retarded fractions eluted on Bio-gel P150 and to the fractions obtained by Ecteola cellulose chromatography. Precipitation with cetylpyridinium was significantly less efficient than elution on Bio-gel P150 as only $10-15 \%$ of the carbohydrate content was recovered whereas the non-retarded fraction, obtained by Biogel chromatography, contained $70-90 \%$ of the carbohydrate content of the gastric aspirates.

BOUND AND FREE SIALIC ACID OF FRACTIONAL GASTRIC ASPIRATES

The free and total sialic acid and the hydrochloric acid content of three fractional gastric aspirates were determined. The results are summarized in Table XI. Fifty $\%-77 \%$ of the sialic acid was found to be free.

CARBOHYDRATE, SULPHATE, AND SIALIC ACID CONTENT OF SIX INDIVIDUAL GASTRIC ASPIRATES AND THEIR NON-RETARDED FRACTIONS ELUTED ON BIO-GEL P150

Pilot experiments had shown that papain digestion did not affect significantly the sialic acid linkage. Six

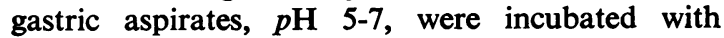
papain and eluted on Bio-gel P150. The sulphate, sialic acid, and carbohydrate composition of each gastric aspirate and the non-retarded fractions were determined. The second and third eluted fractions of one gastric aspirate were also investigated. The 


\begin{tabular}{|c|c|c|c|c|c|c|c|}
\hline \multicolumn{2}{|c|}{ Gastric Glycoprotein } & $\begin{array}{l}\text { Sulphate } \\
\text { (mmolll) }\end{array}$ & $\begin{array}{l}\text { Galactose } \\
(\text { mmolll })\end{array}$ & Fucose & Glucosamine & Galactosamine & $\begin{array}{l}\text { Blood Group } \\
\text { Specificity }\end{array}$ \\
\hline 1 & $\begin{array}{l}\text { Starting }(4 \mathrm{ml}) \\
\text { Non-retarded } \\
1 \\
2\end{array}$ & $\frac{0.66}{0.45}$ & $\begin{array}{l}4.02(4.20) \\
1.56(3.90) \\
1.70(3.76)\end{array}$ & $\begin{array}{l}1.54 \\
0.54 \\
0.65\end{array}$ & $\begin{array}{l}2.82(3.00) \\
1.20(3.00) \\
1.45(3.00)\end{array}$ & $\begin{array}{l}0.91(0.96) \\
0.36(0.90) \\
0.50(1.10)\end{array}$ & $\begin{array}{l}\text { H secretor } \\
\text { H secretor } \\
\text { H secretor }\end{array}$ \\
\hline 2 & $\begin{array}{l}\text { Starting }(8 \mathrm{ml}) \\
\text { Non-retarded } \\
1 \\
2\end{array}$ & $\frac{0.36}{0.42}$ & $\begin{array}{l}2.40(3.80) \\
0.76(3.70) \\
0.90(3.91)\end{array}$ & $\begin{array}{l}1.85 \\
0.56 \\
0.63\end{array}$ & $\begin{array}{l}1.92(3.00) \\
0.64(3.00) \\
0.69(3.00)\end{array}$ & $\begin{array}{l}0.71(1.10) \\
0.22(1.03) \\
0.24(1.04)\end{array}$ & $\begin{array}{l}\text { H secretor } \\
\text { H secretor } \\
\text { H secretor }\end{array}$ \\
\hline 3 & $\begin{array}{l}\text { Starting }(5 \mathrm{ml}) \\
\text { Non-retarded } \\
1 \\
2 \\
\text { Starting }(8 \mathrm{ml})\end{array}$ & $\frac{0.94}{0.70}$ & $\begin{array}{l}5.20(3.71) \\
1.20(3.60) \\
3 \cdot 15(3.93)\end{array}$ & $\begin{array}{l}3 \cdot 45 \\
0 \cdot 50 \\
2 \cdot 15\end{array}$ & $\begin{array}{l}4.32(3.00) \\
1.01(3.00) \\
2.40(3.00)\end{array}$ & $\begin{array}{l}1.24(0.86) \\
0.35(1.03) \\
0.75(0.93)\end{array}$ & $\begin{array}{l}\text { H secretor } \\
\text { H secretor } \\
\text { H secretor }\end{array}$ \\
\hline 5 & $\begin{array}{l}\text { Non-retarded } \\
1 \\
2 \\
\text { Starting }(4 \mathrm{ml})\end{array}$ & $\frac{0.68}{0.60}$ & $\begin{array}{l}4.56(4 \cdot 07) \\
2.60(4 \cdot 00) \\
1 \cdot 35(4 \cdot 22)\end{array}$ & $\begin{array}{l}2.70 \\
1.84 \\
0.84\end{array}$ & $\begin{array}{l}3.36(3.00) \\
1.96(3.00) \\
0.95(3.00)\end{array}$ & $\begin{array}{l}1.33(1.17) \\
0.68(1.04) \\
0.34(1.06)\end{array}$ & $\begin{array}{l}\text { H secretor } \\
\text { H secretor } \\
\text { H secretor }\end{array}$ \\
\hline & $\begin{array}{l}\text { Non-retarded } \\
1 \\
2\end{array}$ & $\frac{1.00}{1.34}$ & $\begin{array}{r}18.00(3.73) \\
11.70(3.90) \\
5 \cdot 16(4.03)\end{array}$ & $\begin{array}{r}10 \cdot 70 \\
7 \cdot 90 \\
3 \cdot 72\end{array}$ & $\begin{array}{r}14.50(3.00) \\
9.00(3.00) \\
3.86(3.00)\end{array}$ & $\begin{array}{l}5.45(1.10) \\
3.37(1.12) \\
1.32(1.03)\end{array}$ & $\begin{array}{l}\text { H secretor } \\
\text { H secretor } \\
\text { H secretor }\end{array}$ \\
\hline 6 & $\begin{array}{l}\text { Starting }(10 \mathrm{ml}) \\
\text { Non-retarded } \\
1 \\
2 \\
\text { Starting }(3 \mathrm{ml})\end{array}$ & $\frac{0.48}{0.55}$ & $\begin{array}{l}5.75(4.16) \\
2.62(3.90) \\
1.82(3.95)\end{array}$ & $\begin{array}{l}5 \cdot 00 \\
2 \cdot 12 \\
1 \cdot 50\end{array}$ & $\begin{array}{l}4.14(3.00) \\
2.02(3.00) \\
1.40(3.00)\end{array}$ & $\begin{array}{l}1.27(0.92) \\
0.63(0.94) \\
0.48(1.04)\end{array}$ & $\begin{array}{l}\text { H secretor } \\
\text { H secretor } \\
\text { H secretor }\end{array}$ \\
\hline 8 & $\begin{array}{l}\text { Non-retarded } \\
1 \\
2 \\
\text { Starting }(10 \mathrm{ml})\end{array}$ & $\frac{0.60}{0.80}$ & $\begin{array}{l}5.36(3.74) \\
2 \cdot 24(3.86) \\
2 \cdot 48(4.00)\end{array}$ & $\begin{array}{l}3.03 \\
1.40 \\
1.68\end{array}$ & $\begin{array}{l}4.30(3.00) \\
1.75(3.00) \\
1.84(3.00)\end{array}$ & $\begin{array}{l}1.41(0.98) \\
0.56(0.96) \\
0.60(0.98)\end{array}$ & $\begin{array}{l}\text { H secretor } \\
\text { H secretor } \\
\text { H secretor }\end{array}$ \\
\hline & $\begin{array}{l}\text { Non-retarded } \\
1 \\
2 \\
3\end{array}$ & $\begin{array}{l}0.58 \\
\frac{0.04}{0.54}\end{array}$ & $\begin{array}{l}2.70(3.86) \\
0.64(4.00) \\
0.45(3.75) \\
1.27(3.84)\end{array}$ & $\begin{array}{l}1 \cdot 60 \\
0 \cdot 40 \\
0 \cdot 30 \\
0 \cdot 72\end{array}$ & $\begin{array}{l}2.10(3.00) \\
0.48(3.00) \\
0.35(3.00) \\
0.99(3.00)\end{array}$ & $\begin{array}{l}0.75(1.07) \\
0.16(1.00) \\
0.12(0.97) \\
0.34(1.03)\end{array}$ & $\begin{array}{l}\text { H secretor } \\
\text { H secretor } \\
\text { H secretor } \\
\text { H secretor }\end{array}$ \\
\hline 9 & $\begin{array}{l}\text { Starting }(7 \mathrm{ml}) \\
\text { Non-retarded } \\
1 \\
2\end{array}$ & $\frac{1.00}{1 \cdot 12}$ & $\begin{array}{l}5.20(3.93) \\
1.72(3.82) \\
2.45(3.76)\end{array}$ & $\begin{array}{l}4 \cdot 30 \\
1.36 \\
1 \cdot 79\end{array}$ & $\begin{array}{l}4.05(3.00) \\
1.36(3.00) \\
1.96(3.00)\end{array}$ & $\begin{array}{l}1.33(0.98) \\
0.44(0.95) \\
0.66(1.01)\end{array}$ & $\begin{array}{l}\text { H secretor } \\
\text { H secretor } \\
\text { H secretor }\end{array}$ \\
\hline 10 & $\begin{array}{l}\text { Starting }(5 \mathrm{ml}) \\
\text { Non-retarded } \\
1 \\
2\end{array}$ & $\frac{0 \cdot 18}{0 \cdot 10}$ & $\begin{array}{l}2.52(3.81) \\
1.16(3.86) \\
1.30(4.33)\end{array}$ & $\begin{array}{l}0 \cdot 71 \\
0 \cdot 44 \\
0 \cdot 60\end{array}$ & $\begin{array}{l}1.98(3.00) \\
0.92(3.00) \\
0.90(3.00)\end{array}$ & $\begin{array}{l}0.63(0.95) \\
0.31(1.01) \\
0.33(1 \cdot 10)\end{array}$ & $\begin{array}{l}\text { H secretor } \\
\text { H secretor } \\
\text { H secretor }\end{array}$ \\
\hline 11 & $\begin{array}{l}\text { Starting }(7 \mathrm{ml}) \\
\text { Non-retarded } \\
1 \\
2\end{array}$ & $\frac{0 \cdot 44}{0 \cdot 14}$ & $\begin{array}{l}5.20(3.70) \\
3.36(3.90) \\
1.01(3.80)\end{array}$ & $\begin{array}{l}4 \cdot 40 \\
3.00 \\
0 \cdot 80\end{array}$ & $\begin{array}{l}4.20(3.00) \\
2.60(3.00) \\
0.84(3.00)\end{array}$ & $\begin{array}{l}2.60(1.20) \\
1.32(1.54) \\
0.49(1.75)\end{array}$ & $\begin{array}{l}\text { A \& H secretor } \\
\text { A \& H secretor } \\
\text { A \& H secretor }\end{array}$ \\
\hline 12 & $\begin{array}{l}\text { Starting }(4 \mathrm{ml}) \\
\text { Non-r etarded } \\
1 \\
2\end{array}$ & $\begin{array}{l}0.36 \\
0.36\end{array}$ & $\begin{array}{l}5.13(4.00) \\
1.20(4.00) \\
1.86(3.87)\end{array}$ & $\begin{array}{l}2 \cdot 80 \\
0 \cdot 72 \\
0.90\end{array}$ & $\begin{array}{l}3.80(3.00) \\
0.90(3.00) \\
1.44(3.00)\end{array}$ & $\begin{array}{l}2.40(1.90) \\
0.48(1.60) \\
0.78(1.70)\end{array}$ & $\begin{array}{l}\text { A \& H secretor } \\
\text { A \& H secretor } \\
\text { A \& H secretor }\end{array}$ \\
\hline 13 & $\begin{array}{l}\text { Starting }(4 \mathrm{ml}) \\
\text { Non-retarded } \\
1 \\
2\end{array}$ & $\frac{0.40}{0.36}$ & $\begin{array}{l}9.10(3.79) \\
4.92(3.91) \\
3.42(3.88)\end{array}$ & $\begin{array}{l}7 \cdot 42 \\
4.08 \\
2 \cdot 64\end{array}$ & $\begin{array}{l}7 \cdot 22(3.00) \\
3.78(3.00) \\
2.64(3.00)\end{array}$ & $\begin{array}{l}3.45(1.43) \\
1.56(1.23) \\
1.14(1.29)\end{array}$ & $\begin{array}{l}\text { A \& H secretor } \\
\text { A \& H secretor } \\
\text { A \& H secretor }\end{array}$ \\
\hline 14 & $\begin{array}{l}\text { Starting }(5 \mathrm{ml}) \\
\text { Non-retarded } \\
1 \\
2\end{array}$ & $\frac{0.36}{0.40}$ & $\begin{array}{l}5.30(3.75) \\
1.80(3.91) \\
1.85(4.10)\end{array}$ & $\begin{array}{l}4.30 \\
1.25 \\
1.40\end{array}$ & $\begin{array}{l}4.25(3.00) \\
1.40(3.00) \\
1.35(3.00)\end{array}$ & $\begin{array}{l}1.80(1.20) \\
0.60(1.30) \\
0.53(1.17)\end{array}$ & $\begin{array}{l}\text { A \& H secretor } \\
\text { A \& H secretor } \\
\text { A \& H secretor }\end{array}$ \\
\hline 15 & $\begin{array}{l}\text { Starting }(4 \mathrm{ml}) \\
\text { Non-retarded } \\
1 \\
2\end{array}$ & $\frac{0.46}{0.36}$ & $\begin{array}{l}3.38(3.75) \\
0.96(4 \cdot 17) \\
1.76(4 \cdot 00)\end{array}$ & $\begin{array}{l}2.58 \\
0.66 \\
1.04\end{array}$ & $\begin{array}{l}2.70(3.00) \\
0.70(3.00) \\
1.30(3.00)\end{array}$ & $\begin{array}{l}1.56(1.73) \\
0.33(1.43) \\
0.65(1.51)\end{array}$ & $\begin{array}{l}\text { A \& H secretor } \\
\text { A \& H secretor } \\
\text { A \& H secretor }\end{array}$ \\
\hline
\end{tabular}

Table VI Carbohydrate and sulphate content of 15 gastric glycoproteins eluted on Ecteola cellulose ${ }^{1}$ ${ }^{1}$ Quantitative relationship between galactose, glucosamine, and galactosamine. (Galactosamine $=3$ ). 


\begin{tabular}{|c|c|c|c|c|c|c|}
\hline \multirow[t]{2}{*}{ Amino Acid } & \multicolumn{6}{|l|}{ Fraction } \\
\hline & Starting & $I$ & 2 & Starting & 1 & 2 \\
\hline $\begin{array}{l}\text { Aspartic acid } \\
\text { Threonıne } \\
\text { Serine } \\
\text { Glutamic acid }\end{array}$ & $\begin{array}{r}1 \cdot 30 \\
10 \cdot 00 \\
5.90 \\
2 \cdot 40\end{array}$ & $\begin{array}{r}1 \cdot 20 \\
10 \cdot 00 \\
6 \cdot 00 \\
2 \cdot 30\end{array}$ & $\begin{array}{r}1 \cdot 40 \\
10 \cdot 00 \\
5 \cdot 80 \\
2 \cdot 40\end{array}$ & $\begin{array}{r}2 \cdot 20 \\
10 \cdot 00 \\
5 \cdot 90 \\
4 \cdot 70\end{array}$ & $\begin{array}{r}0.90 \\
10 \cdot 00 \\
5 \cdot 50 \\
4 \cdot 20\end{array}$ & $\begin{array}{r}2 \cdot 10 \\
10 \cdot 00 \\
5 \cdot 30 \\
3 \cdot 40\end{array}$ \\
\hline Proline & - & - & - & - & - & - \\
\hline $\begin{array}{l}\text { Glycine } \\
\text { Alanine }\end{array}$ & $\begin{array}{l}2 \cdot 20 \\
3 \cdot 60\end{array}$ & $\begin{array}{l}2 \cdot 30 \\
3 \cdot 50\end{array}$ & $\begin{array}{l}2 \cdot 20 \\
3 \cdot 60\end{array}$ & $\begin{array}{l}5 \cdot 80 \\
4 \cdot 50\end{array}$ & $\begin{array}{l}4 \cdot 80 \\
3 \cdot 70\end{array}$ & $\begin{array}{l}4 \cdot 50 \\
5 \cdot 30\end{array}$ \\
\hline Valine & - & $1 \cdot 20$ & - & 1.50 & - & $1 \cdot 70$ \\
\hline Cystine & - & - & - & - & - & - \\
\hline Isoleucine & - & 0.80 & 0.40 & 0.80 & - & 0.90 \\
\hline Leucine & 2.00 & 1.90 & 2.00 & 2.00 & $2 \cdot 20$ & $2 \cdot 40$ \\
\hline Tyrosine & - & - & - & 0.40 & - & 0.70 \\
\hline$\beta$ phenylalanine & - & - & - & $1 \cdot 20$ & 0.90 & 1.00 \\
\hline Lysine & $1 \cdot 10$ & 1.00 & $1 \cdot 20$ & 1.50 & $1 \cdot 10$ & 1.70 \\
\hline Histidine & 1.40 & $1 \cdot 40$ & $1 \cdot 30$ & $1 \cdot 10$ & - & 1.00 \\
\hline Arginine & - & 1.00 & $1 \cdot 10$ & 1.60 & - & 1.00 \\
\hline
\end{tabular}

Table VII Amino acid composition of two glycoproteins and their subfractions eluted on Ecteolacellulose ${ }^{1}$

${ }^{1}$ Values are in molar proportions (threonine $\left.=10\right)$

\begin{tabular}{|c|c|c|c|c|c|c|c|c|}
\hline \multirow[t]{2}{*}{ Fraction } & \multirow{2}{*}{$\begin{array}{l}\text { Total Amino } \\
\text { Acids }\end{array}$} & \multirow[t]{2}{*}{ Total Sugars } & \multirow{2}{*}{$\begin{array}{l}\text { Percentage of } \\
\text { Sugars in } \\
\text { Glycoprotein }\end{array}$} & \multicolumn{2}{|l|}{ Amino Sugars } & \multirow[t]{2}{*}{ Threonine } & \multirow[t]{2}{*}{ Serine } & \multirow{2}{*}{$\begin{array}{l}\text { Blood Group } \\
\text { Specificity }\end{array}$} \\
\hline & & & & Glucosamine & Galactosamine & & & \\
\hline $\begin{array}{c}\text { Starting } \\
\quad 1 \\
2\end{array}$ & $\begin{array}{l}0.93 \\
0.63 \\
0.72\end{array}$ & $\begin{array}{l}5 \cdot 84 \\
2 \cdot 83 \\
3 \cdot 13\end{array}$ & $\begin{array}{l}83 \% \\
81 \% \\
81 \%\end{array}$ & $\begin{array}{l}1.98 \\
0.92 \\
0.90\end{array}$ & $\begin{array}{l}0.63 \\
0.31 \\
0.33\end{array}$ & $\begin{array}{l}0.42 \\
0.19 \\
0.22\end{array}$ & $\begin{array}{l}0.22 \\
0.10 \\
0.13\end{array}$ & $\begin{array}{l}\text { H secretor } \\
\text { H secretor } \\
\text { H secretor }\end{array}$ \\
\hline $\begin{array}{c}\text { Starting } \\
1 \\
2\end{array}$ & $\begin{array}{l}3.43 \\
1.06 \\
1.91\end{array}$ & $\begin{array}{r}14 \cdot 10 \\
5 \cdot 95 \\
6 \cdot 60\end{array}$ & $\begin{array}{l}80 \% \\
84 \% \\
77 \%\end{array}$ & $\begin{array}{l}4 \cdot 30 \\
1 \cdot 75 \\
1 \cdot 84\end{array}$ & $\begin{array}{l}1.41 \\
0.56 \\
0.60\end{array}$ & $\begin{array}{l}1.03 \\
0.32 \\
0.46\end{array}$ & $\begin{array}{l}0.60 \\
0.17 \\
0.25\end{array}$ & $\begin{array}{l}\text { H secretor } \\
\text { H secretor } \\
\text { H secretor }\end{array}$ \\
\hline
\end{tabular}

Table VIII Total amino acid, carbohydrate, threonine and serine content of two glycoproteins and their subfractions eluted on Ecteola cellulose ${ }^{1}$

${ }^{1}$ Quantities are in $\mathrm{mmol} / \mathrm{litre}$.

\begin{tabular}{|c|c|c|c|c|c|}
\hline Sulphate & Galactose & Fucose & Glucosamine & Galactosamine & Blood Group Specificity \\
\hline $\begin{array}{l}0.75 \\
1.06 \\
1.00 \\
0.50 \\
0.75 \\
1.02 \\
2.40 \\
1.30 \\
2.00 \\
0.50 \\
1.21 \\
0.81 \\
1.00 \\
0.59 \\
0.92 \\
0.96 \\
1.93\end{array}$ & $\begin{array}{l}4 \cdot 10 \\
3 \cdot 90 \\
4 \cdot 10 \\
4 \cdot 00 \\
4 \cdot 00 \\
4 \cdot 00 \\
4 \cdot 10 \\
4 \cdot 16 \\
4 \cdot 09 \\
4 \cdot 07 \\
3 \cdot 95 \\
4 \cdot 00 \\
4 \cdot 00 \\
4 \cdot 00 \\
4 \cdot 00 \\
3 \cdot 83 \\
3 \cdot 83\end{array}$ & $\begin{array}{l}2 \cdot 40 \\
2 \cdot 00 \\
2 \cdot 00 \\
2 \cdot 60 \\
2 \cdot 00 \\
2 \cdot 20 \\
2 \cdot 70 \\
3 \cdot 00 \\
2 \cdot 50 \\
3 \cdot 00 \\
2 \cdot 20 \\
2 \cdot 10 \\
2 \cdot 20 \\
2 \cdot 10 \\
1 \cdot 60 \\
1 \cdot 90 \\
2 \cdot 00\end{array}$ & $\begin{array}{l}3.00 \\
3.00 \\
3.00 \\
3.00 \\
3.00 \\
3.00 \\
3.00 \\
3.00 \\
3.00 \\
3.00 \\
3.00 \\
3.00 \\
3.00 \\
3.00 \\
3.00 \\
3.00 \\
3.00\end{array}$ & $\begin{array}{l}1.60 \\
1.30 \\
1.45 \\
1 \cdot 70 \\
1.20 \\
1.50 \\
1.60 \\
1 \cdot 17 \\
1.50 \\
1.70 \\
0.93 \\
1.00 \\
0.93 \\
1.00 \\
1 \cdot 10 \\
0.90 \\
1.20\end{array}$ & $\begin{array}{l}\text { A \& H } \\
\text { A \& H } \\
\text { A \& H } \\
\text { A \& H } \\
A \text { \& H } \\
\text { A \& H } \\
A \text { \& H } \\
\text { A \& H } \\
\text { A \& H } \\
\text { A \& H } \\
\text { H secretor } \\
\text { H secretor } \\
\text { H secretor } \\
\text { H secretor } \\
\text { Non-secretor } \\
\text { Non-secretor } \\
\text { Non-secretor }\end{array}$ \\
\hline
\end{tabular}

Table IX Ratio of carbohydrate and sulphate components of cetylpyridinium chloride precipitates ${ }^{1}$

${ }^{2}$ Ratio of carbohydrate components and sulphate to glucosamine $=3$ 


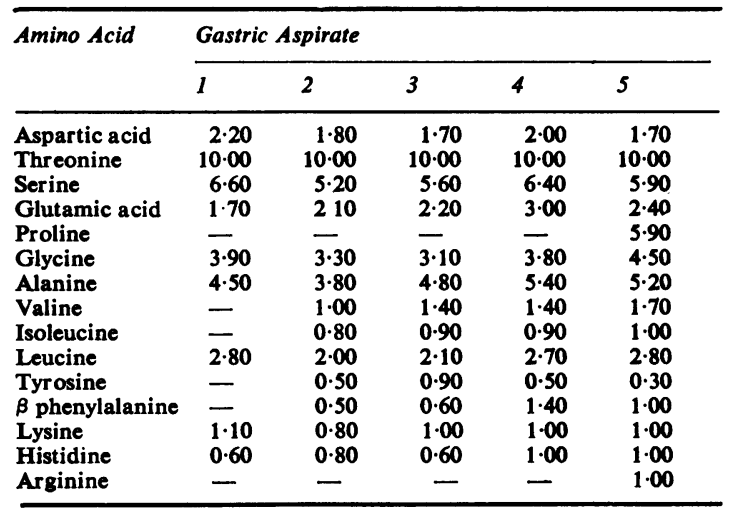

Table X Amino acid composition of cetylpyridinium chloride precipitates of five gastric aspirates 1

\begin{tabular}{lllc}
\hline $\begin{array}{l}\text { Gastric } \\
\text { Aspiration }\end{array}$ & \multicolumn{2}{l}{ Sialic Acid (mmolllitre) } & $\mathrm{HCl}$ (cm-equiv/litre) \\
\cline { 2 - 3 } & Total & Free & \\
\hline 1 & 0.26 & 0.15 & 5 \\
2 & 0.67 & 0.32 & 15 \\
3 & 0.22 & 0.15 & 32 \\
4 & 0.14 & 0.09 & 60 \\
5 & 0.10 & 0.07 & 84 \\
6 & 0.18 & 0.14 & 90 \\
7 & 0.19 & 0.13 & 100 \\
8 & 0.12 & 0.08 & 115 \\
\hline
\end{tabular}

Table XI Total and free sialic acid of eight acidic gastric aspirations

${ }^{1}$ Values are in molar proportions (threonine $\equiv 10$ )

\begin{tabular}{|c|c|c|c|c|c|c|c|}
\hline \multirow[t]{2}{*}{ Sulphate } & \multicolumn{2}{|c|}{ Sialic Acid } & \multirow[t]{2}{*}{ Galactose } & \multirow[t]{2}{*}{ Fucose } & \multirow[t]{2}{*}{ Glucosamine } & \multirow[t]{2}{*}{ Galactosamine } & \multirow{2}{*}{$\begin{array}{l}\text { Blood Group } \\
\text { Specificity }\end{array}$} \\
\hline & Free & Total & & & & & \\
\hline $\begin{array}{l}\text { Four Gas } \\
1.90 \\
2.04 \\
2.30 \\
1.90\end{array}$ & $\begin{array}{l}\text { es } \\
0.37 \\
\text { Nil } \\
0.54 \\
0.65\end{array}$ & $\begin{array}{l}0.80 \\
0.64 \\
1 \cdot 16 \\
1 \cdot 20\end{array}$ & $\begin{array}{l}2.08 \\
2 \cdot 91 \\
4 \cdot 85 \\
6 \cdot 55\end{array}$ & $\begin{array}{l}0 \cdot 79 \\
2 \cdot 18 \\
4 \cdot 07 \\
5 \cdot 30\end{array}$ & $\begin{array}{l}1 \cdot 86 \\
2 \cdot 83 \\
4 \cdot 00 \\
6 \cdot 80\end{array}$ & $\begin{array}{l}0 \cdot 56 \\
0.94 \\
1 \cdot 17 \\
2 \cdot 57\end{array}$ & $\begin{array}{l}\text { A \& H secretor } \\
\text { H secretor } \\
\text { H secretor } \\
\text { H secretor }\end{array}$ \\
\hline $\begin{array}{l}\text { Non-retar } \\
0 \cdot 18 \\
0.28 \\
0.20 \\
0.20\end{array}$ & ns of $F c$ & $\begin{array}{l}\text { Aspira } \\
0.006 \\
0.033 \\
\text { Nil } \\
\text { Nil }\end{array}$ & $\begin{array}{l}0.36 \\
0.91 \\
0.83 \\
1 \cdot 14\end{array}$ & $\begin{array}{l}0.15 \\
0.56 \\
0.59 \\
0.74\end{array}$ & $\begin{array}{l}0.28 \\
0.69 \\
0.64 \\
0.91\end{array}$ & $\begin{array}{l}0 \cdot 11 \\
0 \cdot 25 \\
0 \cdot 23 \\
0 \cdot 31\end{array}$ & $\begin{array}{l}\text { A \& H secretor } \\
\text { H secretor } \\
\text { H secretor } \\
\text { H secretor }\end{array}$ \\
\hline \multicolumn{2}{|c|}{$\begin{array}{l}\text { Gastric Aspirate pH } 6.5 \\
\text { Gastric aspirate } \\
\text { Non-retarded fraction } \\
\text { 2nd peak } \\
\text { 3rd peak }\end{array}$} & $\begin{array}{l}2 \cdot 14 \\
0 \cdot 21 \\
0 \cdot 50 \\
1 \cdot 40\end{array}$ & $\begin{array}{r}16 \cdot 50 \\
12 \cdot 30 \\
0 \cdot 41 \\
6 \cdot 00\end{array}$ & $\begin{array}{r}11 \cdot 80 \\
8 \cdot 20 \\
0 \cdot 41 \\
3 \cdot 20\end{array}$ & $\begin{array}{r}14 \cdot 80 \\
9 \cdot 45 \\
0 \cdot 52 \\
5 \cdot 20\end{array}$ & $\begin{array}{l}4 \cdot 55 \\
3.30 \\
0 \cdot 09 \\
1 \cdot 20\end{array}$ & $\begin{array}{l}\text { H secretor } \\
\text { H secretor } \\
\text { H secretor } \\
\text { H secretor }\end{array}$ \\
\hline
\end{tabular}

Table XII Sulphate, sialic acid, and carbohydrate composition of four gastric aspirates $\mathrm{pH}$ 5-7 at time of aspiration, their non-retarded fractions, and a gastric aspirate $\mathrm{pH} 6.5$

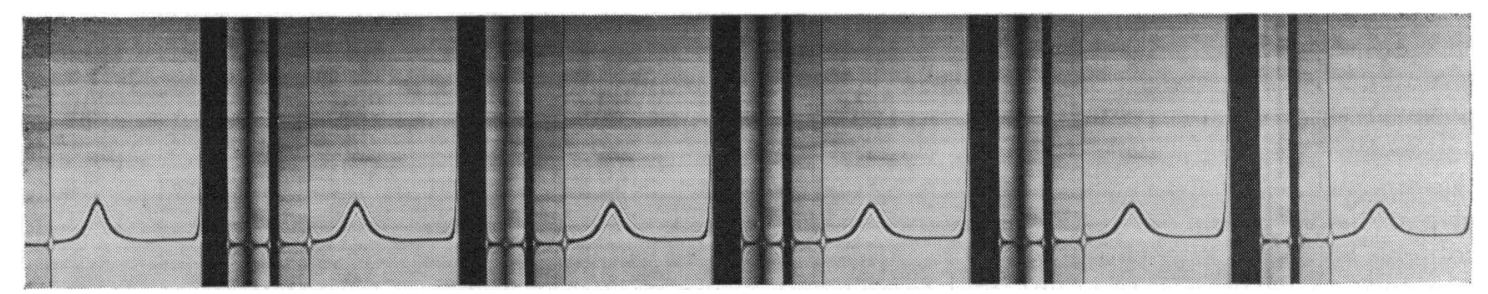

Fig. 3 Ultracentrifugation of a non-retarded fraction of gastric secretion eluted on Bio-gel P150.

Ultracentrifugation conditions were: $59780 \mathrm{rpm}$, temperature $20^{\circ} \mathrm{C}$, approximately $1.5 \mathrm{mg} / \mathrm{ml}$ in $0.2 \mathrm{M}$ sodium chloride. 
results are summarized in Table XII. The nonretarded fractions contained only traces of sialic acid (Table XII). The bulk of the sialic acid was distributed between the second and third fractions (Table XII). It is to be noticed that the sialic acid and carbohydrate composition of the second and third fractions are similar to that of the plasma glycoproteins (Shultze and Heremans, 1966) and so is the the sialic acid:mannose ratio.

ULTRACENTRIFUGATION STUDIES

Ultracentrifugation studies of the glycoprotein revealed a uniform peak suggesting homogeneity within the limits of this method (Fig. 3).

\section{Discussion}

The results of this investigation suggest that the composition of the non-retarded fractions of whole gastric aspirates eluted on Bio-gel P150 are virtually the same as the non-retarded fractions of the eluted supernatant reported previously (Schrager and Oates, 1970).

The analytical data on the carbohydrate and amino acid composition, with regard to the common basic quantitative relationship of galactose:glucosamine: galactosamine, 4:3:1, and the quantitative relationship between galactosamine and the two hydroxy amino acids, suggests that the non-retarded fraction is composed of a population of glycoproteins with a constant basic structure but polydisperse with respect to the sulphate content and the terminal sugar residues which are associated with blood group specificity. These additional sugar residues divide the glycoproteins into groups, each group with a distinctive carbohydrate residue which bestows on the glycoproteins a characteristic blood group specificity. The amino acid composition of the protein moiety was found to be similar in all glycoproteins investigated; the threonine and serine content was between $45-50 \%$ and the threonine: serine ratio was approximately $2: 1$.

The isolation of a tolerably pure gastric glycoprotein with respect to its amino acids presents special difficulties. The protein moiety of the gastric glycoprotein accounts for $15-20 \%$ whereas in the plasma glycoprotein it accounts for between 90 and and $97 \%$ of the total molecule (Porter, 1967); hence the presence of even very small amounts of plasma glycoproteins would affect greatly the protein content of the gastric glycoprotein. Any attempt, therefore, to determine the amino acid composition of the gastric glycoprotein accurately requires the complete removal of all plasma glycoprotein fragments. It cannot be claimed that all contaminating materials were completely removed; some may even have been absorbed within the glycoprotein macromolecules. Despite these difficulties the amino acid composition was found to be approximately constant within the limits of the experimental error.

The chromatography for a second time of the non-retarded fraction on Ecteola cellulose provided subfractions which had a similar carbohydrate and amino acid composition and did not differ from the non-retarded fraction before chromatography. The fractions eluted on Ecteola cellulose differed only in their sulphate content. The cetylpyrodinium chloride precipitates showed a similar carbohydrate and amino acid composition as the non-retarded fractions and the subfractions obtained from Ecteola chromatography. The constancy of analysis by independent purification procedures supports the above concept.

The data also suggest that the isolated glycoprotein is the principal carbohydrate-containing fraction of the gastric secretion as it contained 68$96 \%$ of the carbohydrate content of the gastric aspirate. Some of the remaining $4-32 \%$ of the carbohydrate content will be accounted for by plasma glycoproteins found in the gastric secretion. The presence of other minor glycoproteins cannot be excluded as the total carbohydrate content has yet to be accounted for.

The study of the sialic acid content of the nonretarded fraction of gastric aspirates presents special difficulties. The data summarized in Table XI show that $50-77 \%$ of the sialic acid was free. The high percentage of free sialic acid is very likely due to the acid labile linkage which is cleaved off in the acidic aspirations.

An attempt was, therefore, made to study the sialic acid content of gastric aspirates with a neutral or near neutral $p \mathrm{H}$ and the non-retarded fractions of these aspirates eluted on Bio-gel P150 (Table XII). The sialic acid distributed between the first (nonretarded fraction), second and third fractions of one gastric aspirate was also determined (Table XIIc). The non-retarded fractions contained only minimal amounts or traces of sialic acid (Table XIIb). The values of sialic acid which varied between nil and $0.05 \mathrm{M}$ per $\mathrm{M}$ of glucosamine indicate that the major part of the sialic acid content of the gastric aspirate is contributed by the plasma glycoproteins which contain considerable quantities of sialic acid (Schultze and Heremans, 1966). This suggestion is supported by the distribution of the sialic acid between the non-retarded fraction and the second and third peak eluted on Bio-gel P150. Ninety-three percent of the sialic acid content found in the gastric aspirate was distributed between the second and third retarded fractions (Table XII). These fractions have a carbohydrate composition and a sialic acid: 
mannose ratio similar to that found in plasma glycoproteins (Schultze and Heremans, 1966).

The results of this investigation demonstrate the polyanionic character of the gastric glycoproteins with varying amounts of sulphate as the main charged group. The sulphate content of the isolated gastric glycoprotein varied between zero and a sulphate:glucosamine ratio of $2: 3$. The subfractions of the non-retarded fraction eluted on Ecteola cellulose showed that $20-50 \%$ of the glycoproteins were sulphated.

One is led to consider two alternative assumptions. The first assumption would be that the gastric mucosa secretes two species of glycoproteins, namely, sulphated glycoproteins and non-sulphated glycoproteins. A corollary to this assumption would be that the sulphated glycoproteins are present in discrete components, each component with a characteristic sulphate content. The second possibility is that the non-retarded fraction is composed of glycoproteins with a wide range in degree of sulphation.

It is tempting to speculate on the biological significance and the purpose served by the variability found in the degree of sulphation. The strength of the three-dimensional network which probably constitutes mucus may depend largely on the sulphate content which produces sites for ionic cross linking. An increase in the sulphate content would increase the strength of the network; a reduction in sulphate and a decrease in the number of sites for ionic cross linking would loosen the structure. It would lower the viscosity, as the macromolecule itself is highly soluble due to its high carbohydrate content; therefore, any sulphate change in the glycoprotein may be reflected in the stability of mucus.

Excessive fluidity is seemingly as undesirable as excessive rigidity. The latter would cause difficulty in the removal of mucus and would set up local irritation and obstruction. The correct degree of gelation may depend on the concentration of the glycoprotein in the gastric secretion; the sulphate content of the glycoprotein; and the ratio of the non. sulphated to sulphated glycoprotein. The range of changes of these variables, their physiological limits, the effect of these changes on the gelation and integrity of the mucus layer and their relationship to gastric pathology have yet to be investigated.

\section{References}

Babkin, P. P. (1950). Secretory Mechanism of the Digestive Glands, 2nd. ed. Hoeber, New York.

Boorman, K. E., and Dodd, B. E. (1966). An Introduction to Blood Group Serology, 3rd ed., pp. 61-66. Churchill, London.

Lloyd, K. O., Kabat, E. A., and Licerio, E. (1968). Immunochemical studies on blood groups. XXXVIII. Structures and activities of oligosaccharides produced by alkaline degradation of bloodgroup Lewis substance. Proposed structure of the carbohydrate chains of human blood-group A, B, H, Le and Le substances. Biochemistry (Wash.), 7, 2976-2990.

Martin, F., Mathian, R., Ber ard, A., and Lambert, R. (1969). Sulfated glycoproteins in human salivary and gastric secretions. Digestion, 2, 103-112.

Morgan, W. T. J., and Watkins, W. M. (1969). Genetic and biochemical aspects of human blood-group A-, B-, H-, Le $\mathrm{L}_{-}^{\mathrm{a}}$ and $\mathrm{Le}^{\mathrm{b}_{-}}$ specificity. Brit. med. Bull., 25, 30-34.

Porter, R. R. (1967). The structure of immunoglobulins. Essays Biochem., 3, 1-24.

Schrager, J. (1964). Sulphated mucopolysaccharides of the gastric secretion. Nature (Lond.), 201, 702-704.

Schrager, J., and Oates, M. D. G. (1970). Further observations on the principal glycoprotein of the gastric secretion. Digestion, 3, 231-242.

Schultze, H. E., and Heremans, J. F. (1966). Molecular Biology of Human Proteins, Vol. 1, pp. 773-815. Elsevier, Amsterdam. 